\title{
Variations in carbon and nitrogen stable isotopes and in heavy metal contents of mariculture kelp Undaria pinnatifida in Gijang, southeastern Korea
}

\author{
JeongHee Shim ${ }^{1, *}$, Jeong Bae Kim², Dong-Woon Hwang ${ }^{2}$, Hee-Gu Choi ${ }^{2}$ and Yoon Lee ${ }^{1}$ \\ ${ }^{1}$ Fisheries Resources and Environment Research Division, East Sea Fisheries Research Institute, NIFS, Gangneung 25435, \\ Korea \\ ${ }^{2}$ Marine Environment Research Division, NIFS, Busan 46083, Korea
}

Korean mariculture Undaria pinnatifida was collected during the months of January, February, March, and December of 2010 , as well as from January of 2011 to investigate the changes in the carbon and nitrogen stable isotope ratios $\left(\delta^{13} \mathrm{C}\right.$ and $\left.\delta^{15} \mathrm{~N}\right)$ and heavy metal with respect to it growth and to identify the factors that influence such changes. The blades of $U$. pinnatifida showed $\delta^{13} \mathrm{C}$ and $\delta^{15} \mathrm{~N}$ in the range (mean) of -13.11 to $-19.42 \%$ (-16.93\%) and 2.99 to $7.57 \%$ (4.71\%o), respectively. Among samples with the same grow-out period, those that weighed more tended to have higher $\delta^{13} \mathrm{C}$ suggesting a close association between the carbon isotope ratio and growth rate of $U$. pinnatifida. Indeed, we found a very high positive linear correlation between the monthly average $\delta^{13} \mathrm{C}$ and the absolute growth rate in weight $\left(\mathrm{r}^{2}=0.89\right)$. Nitrogen isotope ratio tended to be relatively lower when nitrogen content in the blade was higher, probably due to the strengthening of isotope fractionation stemming from plenty of nitrogen in the surrounding environment. In fact, a negative linear correlation was observed with the nitrate concentration in the nearby seawaters $\left(\mathrm{r}^{2}=0.83\right)$. Concentrations of $\mathrm{Cu}, \mathrm{Cd}, \mathrm{Pb}, \mathrm{Cr}, \mathrm{Hg}$, and $\mathrm{Fe}$ in the blades showed a rapid decrease in their concentration per unit weight in the more mature U. pinnatifida. Specifically, compared to adult samples, $\mathrm{Cu}, \mathrm{Hg}$, and $\mathrm{Pb}$ were concentrated by 30,55 , and 73 folds, respectively, in the young blades. Therefore, U. pinnatifida tissue $\delta^{13} \mathrm{C}$ is as an indirect indicator of its growth rate, while $\delta^{15} \mathrm{~N}$ values and heavy metal concentrations serve as tracers that reflect the environmental characteristics.

Key Words: carbon isotope; growth rate; mariculture; metal; nitrogen isotope; Undaria pinnatifida

\section{INTRODUCTION}

Macroalgae directly assimilate materials from the environment for growth, and subsequently deliver energy to the upper trophic levels by becoming a food source for the herbivorous organisms next up in the food chain. Among the biogeochemical components of macroalgae, it is essential to understand the distribution of major components of metabolic processes, namely $\mathrm{C}, \mathrm{N}$, and heavy metals within the organism (Klenell et al. 2004, Ale et al. 2011, Oakes and Eyre 2015). Such information is not only useful in identifying the ecological food chain but also in accurately reflecting the characteristics of the marine environment under consideration. Recent researches have attempt to connect carbon and nitrogen isotope ratios $\left(\delta^{13} \mathrm{C}\right.$ and $\left.\delta^{15} \mathrm{~N}\right)$ in marine macrophytes with their physical and biogeochemical environment
(9) \$ This is an Open Access article distributed under the terms of the Creative Commons Attribution Non-Commercial License (http://creativecommons.org/licenses/by-nc/3.0/) which permits unrestricted non-commercial use, distribution, and reproduction in any medium, provided the original work is properly cited.
Received August 17, 2017, Accepted December 3, 2017

*Corresponding Author

E-mail: jshim@korea.kr

Tel: +82-33-660-8534, Fax: +82-33-661-3923 
(Carvalho et al. 2010, Mackey et al. 2015, Oakes and Eyre 2015, Orlandi et al. 2017). Some studies suggested that the $\delta^{13} \mathrm{C}$ and $\delta^{15} \mathrm{~N}$ in macroalgae can be used as indirect index of growth rate and tracer for $\mathrm{N}$ sources, respectively (Carvalho et al. 2009, Piñón-Gimate et al. 2017). Studies on carbon and nitrogen isotope ratios in macroalgae in Korea are limited to those measured in the adults for investigation of food sources (Yun et al. 2006, Kang et al. 2007, Park et al. 2016), whereas studies related to heavy metals have involved measurement of only adult organisms or indoor assimilation characteristics (Lee et al. 1989, Park et al. 2012). However, macroalgae have very active material uptake and physiological activities that are highly sensitive to the environmental changes (Kim et al. 2015). Moreover, the distribution of biochemical components within the same species can vary greatly according to the season, growth stage, parts of the organism sampled, and also based on the habitat itself. Therefore, it is imperative to conduct precise investigation by subcategorizing each of the factors mentioned above.

The natural habitat of the Undaria pinnatifida is the subtidal zones across the coastal regions of Korea. Based on the annual averages between the years 2006-2015, the annual production from shallow-sea farming is approximately 340,000 tons ( 6.13 billion KRW); accounting for $35.8 \%$ of the total macroalgae production. Indeed, $U$. pinnatifida yields the highest mass production among all the local macroalgae varieties (Korean Statistical Information Service, http://www. kosis.kr).

Here, we evaluate the characteristics of $\mathrm{C}$ and $\mathrm{N}$ stable isotope ratio, heavy metal content of $U$. pinnatifida, maricultured in Gijang on the east coast of Korea, and also investigate the variations in these parameters brought about by growth and seasonality. The study also aimed to use these findings as the basis for accurate assessment of ecological food sources, material cycling, and discrimination of origin. Especially in the high- $\mathrm{CO}_{2}$ world (ocean acidification) of today, carbon isotope ratio would help to gain a greater understanding of the carbon cycle, whereas the nitrogen isotope ratio and heavy metal data would be helpful in determining their applicability as environmental biomonitors for the inflow of pollutants from the land.

\section{MATERIALS AND METHODS}

\section{Sampling and morphological information}

Samples of the kelp Undaria pinnatifida from the coast of Gijang, grown-out via a longline method in floating raft, were collected during the months of January, February, March, and December of 2010 and only January of 2011. After seeding in an indoor-hatchery with strings in a frame, seeded-strings were transplanted to floating ropes in the open water during late fall. The seaweed samples collected during January-March 2010 were transplanted in October of 2009, whereas those collected during December 2010 and January 2011 were transplanted in November of 2010 (Table 1). After transporting the collected samples to the laboratory, the samples were thoroughly washed with fresh water to remove any epiphytes attached to the surface of the thallus. After wiping the moisture from the samples, the fresh wet weight of each thallus was measured in every 2-4 samples at the correcting days $(\mathrm{n}=17)$. The morphological characteristics of the blade, such as its length, width, and area, were determined by analyzing the images taken by placing the samples on the top of grids. The samples used in the experiments were transplanted in the ocean for about 49-153 days and were relatively evenly distributed between the different growth stages. Overall, the blade length and width ranged between 20-106 and 3-55 cm, respectively, whereas wet weight ranged from 1 to $90 \mathrm{~g}$. The growth rates in blade weight were calculated by measuring changes in the mean fresh wet weights of 2-4 samples for each correcting interval with $0.2 \mathrm{~g}$ for beginning seeds weight.

Table 1. Sampling and morphological information for Undaria pinnatifida maricultured in Gijang on the east coast of Korea from January 2010 to January 2011

\begin{tabular}{lcccccc}
\hline \multicolumn{1}{c}{$\begin{array}{c}\text { Date of } \\
\text { sampling }\end{array}$} & $\begin{array}{c}\text { Date of } \\
\text { sea-transplanted }\end{array}$ & $\begin{array}{c}\text { Days after } \\
\text { transplanted (day) }\end{array}$ & $\begin{array}{c}\text { Wet weight } \\
(\mathbf{g})\end{array}$ & $\begin{array}{c}\text { Surface area } \\
\left(\mathbf{c m}^{2}\right)\end{array}$ & $\begin{array}{c}\text { Blade length } \\
(\mathbf{c m})\end{array}$ & $\begin{array}{c}\text { Blade width } \\
(\mathbf{c m})\end{array}$ \\
\hline Jan 11, 2010 & Oct 28, 2009 & 76 & $21.4-45.8$ & $450-1,087$ & $61-88$ & $24-39$ \\
Feb 2, 2010 & Oct 28, 2009 & 98 & $22.6-75.7$ & $416-1,826$ & $64-85$ & $26-55$ \\
Mar 11, 29, 2010 & Oct 28, 2009 & $135-153$ & $41.5-89.6$ & $670-943$ & $81-106$ & $31-46$ \\
Dec 20, 2010 & Nov 3, 2010 & 49 & $0.9-2.8$ & $44-98$ & $20-29$ & $3-6$ \\
Jan 19, 2011 & Nov 23, 2010 & 58 & $2.9-11.9$ & $105-284$ & $28-50$ & $6-16$ \\
\hline
\end{tabular}




\section{Chemical analysis}

Stable isotope and elemental analysis. For the analysis of stable isotopes of carbon and nitrogen from blade of $U$. pinnatifida, samples were dried for $48 \mathrm{~h}$ at $60^{\circ} \mathrm{C}$ before grinding them using a ball mill (Pulverisette 23; Fritsch, Idar-Oberstein, Germany). The resulting homogeneous powder was put in tin capsules, 0.6-15 mg each, and weighed. The $\mathrm{C}$ and $\mathrm{N}$ stable isotopes in the samples were analyzed using an isotope ratio-mass spectrometer (IsoPrime 100; Micromass, Manchester, UK) connected to a CNS elemental analyzer (Vario ISOTOPE Select; Elementar, Langenselbold, Germany). The stable isotope ratio of the samples was expressed as parts per thousand relative to the isotope ratio of the international standard material, as shown in the equation below.

$$
\delta \mathrm{X}(\% 0)=\left[\left(\mathrm{R}_{\text {sample }} / \mathrm{R}_{\text {standard }}\right)-1\right] \times 1,000
$$

$\mathrm{X},{ }^{13} \mathrm{C}$ or ${ }^{15} \mathrm{~N}, \mathrm{R}$ is the ratio of the heavy-to-light isotope, $\mathrm{R}_{\text {sample }}$ is that ratio in the sample, and $\mathrm{R}_{\text {standard }}$ is that in the standard.

Pee Dee Belemnite was used as the standard material for $\mathrm{C}$, whereas atmospheric $\mathrm{N}_{2}$ was used as the standard material for N. Precision and reproducibility of the mass spectrometer were tested by analyzing 20 samples of EMA-P2 polymers (Elemental Microanalysis, Devon, UK). The standard deviation (SD) of the stable isotope ratio for carbon and nitrogen showed high reliability with \pm 0.2 and $\pm 0.3 \%$ o SD, respectively. To determine the carbon and nitrogen content in the blade samples, the homogenized powder was put in tin capsules, 0.5-1 mg each, and weighed, followed by further downstream analysis using a CHN elemental analyzer (Flash EA 1112; Thermo Finnigan, Italy).

Heavy metal analysis. All samples collected for metal analysis were freeze-dried at $-80^{\circ} \mathrm{C}$ in a vacuum freeze dryer and then were homogenized in a jar using a mixer mill. Approximately $1.0 \mathrm{~g}$ of each powdered sample was placed in a digestion vessel with a lid (Teflon; Savillex Corp., Eden Prairie, MN, USA) and was digested with 10 $\mathrm{mL}$ of conc. $\mathrm{HNO}_{3}$ (Suprapur grade; Merck, Darmstadt, Germany) at $80^{\circ} \mathrm{C}$ for $7 \mathrm{~h}$. Next, the digested extracts were dried by heating the vessel without lids at $100^{\circ} \mathrm{C}$ for $3 \mathrm{~h}$. This procedure was repeated twice or thrice. Subsequently, the residues were dissolved in $80 \mathrm{~mL}$ of $2 \% \mathrm{HNO}_{3}$, and the solution was filtered using filter paper $(5 \mathrm{C}, 110 \mathrm{~mm}$; Adventec, Dublin, CA, USA). The filtered solution was diluted to the required final volume $(100 \mathrm{~mL})$ with $2 \% \mathrm{HNO}_{3}$ before any instrumental analysis. Finally, the concentra- tion of $\mathrm{Cd}, \mathrm{Cr}, \mathrm{Cu}, \mathrm{Fe}$, and $\mathrm{Pb}$ in the filtrate was determined by using an inductively coupled plasma mass spectrometer (ICP-MS, Elan DRC-e; PerkinElmer, Shelton, CT, USA). The concentration of $\mathrm{Hg}$ in the dried fine samples was determined directly by using automated mercury analyzers (DMA 80; Milestone, Sorisole, Italy). The DOLT-4 and DORM-3 (National Research Council Canada), certified reference materials for trace elements, were used for all except Hg. Additionally, ERM-CE278 (European Commission) was used as a reference material for $\mathrm{Hg}$ levels as well as to validate the accuracy of the previous metal analysis. These three certified reference materials were measured following identical protocol as the samples, and the average recovery ranged from $86 \%$ for $\mathrm{Pb}$ to $128 \%$ for $\mathrm{Cr}$. All analytical procedures were performed in a class 100 clean room to prevent potential contamination.

\section{Data analysis}

The Pearson Correlation was carried out to study the relationships between metal concentrations and blade properties, and the Levene's test was used to test for homogeneity of metal concentration data. The statistical analyses were performed using the IBM SPSS for Windows software package ver. $12.0 \mathrm{~K}$ (IBM Corp., Armonk, NY, USA) and $\mathrm{p}<0.05$ was considered to indicate statistical significance.

\section{RESULTS}

\section{Carbon and nitrogen contents and their respec- tive stable isotope ratios}

The carbon stable isotope ratio $\left(\delta^{13} \mathrm{C}\right)$ from blade of $U n$ daria pinnatifida collected from the Gijang region ranged from -13.11 to $-19.42 \%$, with a mean value of $-16.93 \%$ (Fig. 1A). The corresponding range for organic carbon content was $24.6-33.7 \%$, with a mean value of $29.2 \%$ (Fig. 1A). Monthly averages of carbon isotope ratios became progressively lower from January (76-day posttransplant) to March (153-day post-transplant) of 2010, whereas the 2011 samples, that were transplanted in November of 2010, showed a tendency towards an increase from December (49-day post-transplant) to January (58day after transplanted). Specifically, samples collected in the month of January of either 2010 or 2011 showed values of -15.30 and $-16.38 \%$, respectively, which were relatively higher than the values for samples from the other months. For the organic carbon content, samples from January to March 2010 showed values $\geq 30 \%$, which was 

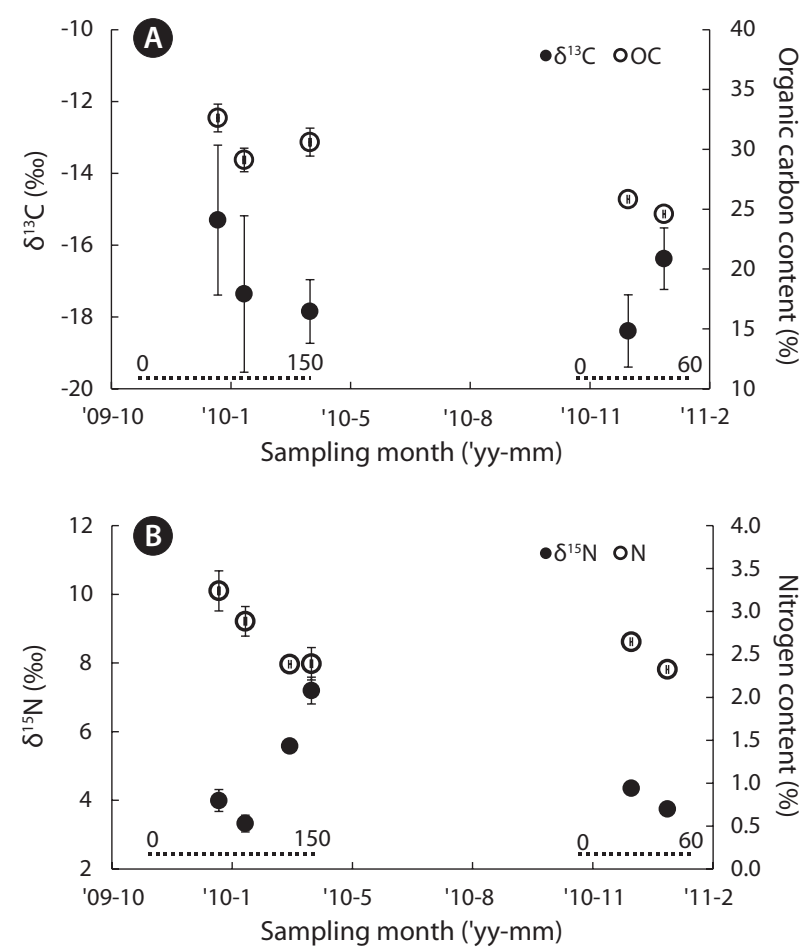

Fig. 1. Variations of monthly mean contents and stable isotope ratios of carbon (A), and those of nitrogen (B) for Undaria pinnatifida maricultured in Gijang on the east coast of Korea from January 2010 to January 2011. Dotted lines below represent the days after transplanted.

4 to $5 \%$ higher than those observed in December 2010 and January 2011 samples, arguably due to the relatively shorter grow-out period of this batch.

The range and the mean of the nitrogen isotope ratio $\left(\delta^{15} \mathrm{~N}\right)$ were $2.99-7.57$ and $4.71 \%$, respectively (Fig. $1 \mathrm{~B}$ ). The range and mean of the nitrogen content were 2.13.5 and $2.7 \%$, respectively (Fig. 1B). The nitrogen isotope ratio in samples collected from 2010 was progressively higher from January to March, while samples from the 2011 batch showed comparable values in December and January, with January ratios being slightly lower. However, from January to March 2010, there was a distinct decline in nitrogen content in the seaweed blade samples. Notably, the values for December 2010 and January 2011 were similar to those observed between February and March. Nitrogen isotope tends to be lighter when nitrogen content is higher. Overall, the mean monthly $\mathrm{C} / \mathrm{N}$ ratio of seaweed blade samples was 9.3-13.0, which indicated a positive linear correlation during the grow-out period. Samples collected in the month of December, with the shortest grow-out period, had the lowest value; whereas March samples emerged with a peak value of $13.0\left(\mathrm{r}^{2}=\right.$ 0.62).
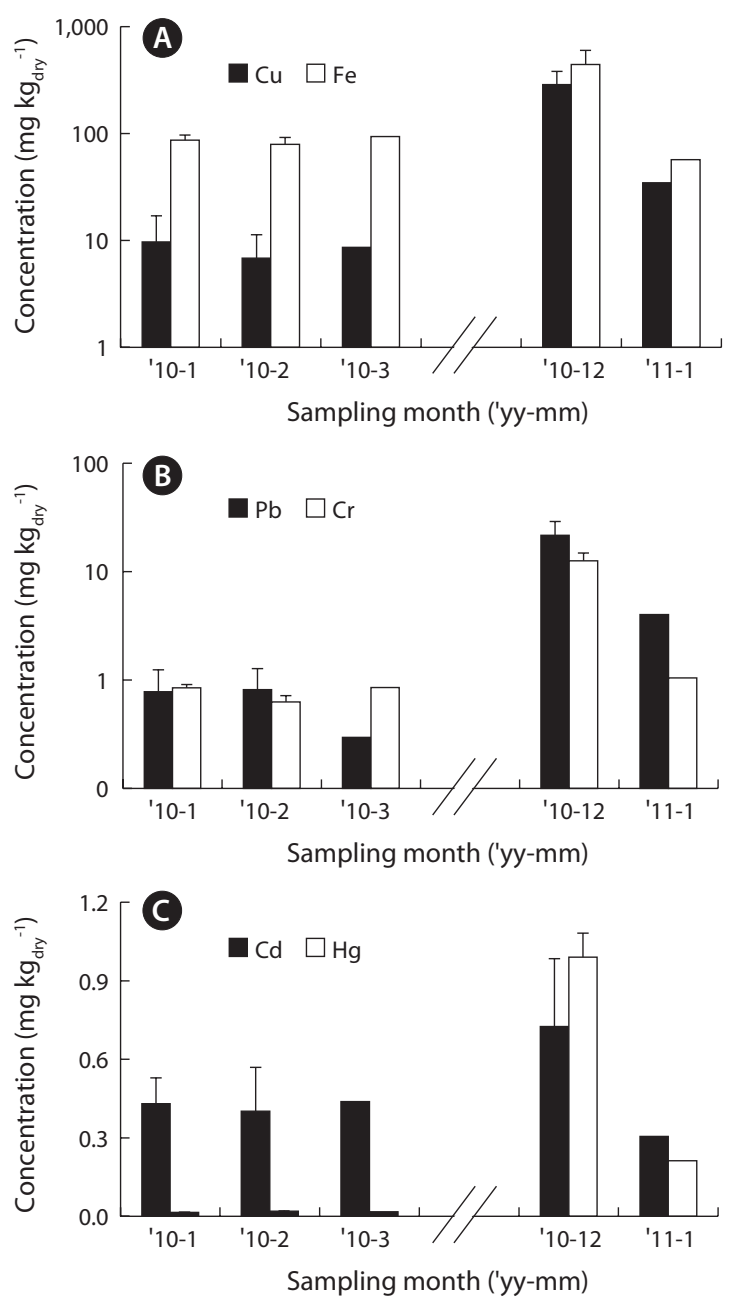

Fig. 2. Variations of monthly mean concentrations ( $\left.\mathrm{mg} \mathrm{kg}_{\mathrm{dry}}{ }^{-1}\right)$ of $\mathrm{Cu}$ and $\mathrm{Fe}(\mathrm{A}), \mathrm{Pb}$ and $\mathrm{Cr}(\mathrm{B})$, and $\mathrm{Cd}$ and $\mathrm{Hg}$ (C) for Undaria pinnatifida maricultured in Gijang on the east coast of Korea from January 2010 to January 2011.

\section{Tissue heavy metals}

The concentration of heavy metals $(\mathrm{Cu}, \mathrm{Cd}, \mathrm{Pb}, \mathrm{Cr}$, $\mathrm{Hg}$, and $\mathrm{Fe}$ ) in the seaweed blades was measured and expressed as monthly average values (Fig. 2). Cu concentration in the seaweed samples was 6.9-9.7 $\mathrm{mg} \mathrm{kg}_{\text {dry }}{ }^{-1}$ during January to March of 2010, showing little variation between the months; but the concentration in December was about 30 folds higher at $287.1 \mathrm{mg} \mathrm{kg}_{\text {dry }}{ }^{-1}$, which decreased again in January of 2011 to $34.6 \mathrm{mg} \mathrm{kg}_{\text {dry }}{ }^{-1}$. These results indicate that young blades have higher Cu content per unit weight than adults, and, the samples from about 80 days after transplantation or samples with a blade length of $\geq 70 \mathrm{~cm}$, have small variations in the $\mathrm{Cu}$ concentration (within 2-3 folds). For $\mathrm{Pb}, \mathrm{Cr}, \mathrm{Cd}, \mathrm{Hg}$, and $\mathrm{Fe}$, 
their concentration in seaweed blade samples spanned from 0.3-21.7, 0.63-12.6, 0.31-0.73, 0.02-0.99, and 57.0$441.3 \mathrm{mg} \mathrm{kg}_{\text {dry }}{ }^{-1}$, respectively. Similar to $\mathrm{Cu}$, most of the heavy metals were present at lower concentrations in the adult samples obtained in March and at higher concentrations in the young samples in December. Particularly, the concentration of $\mathrm{Pb}$ and $\mathrm{Hg}$ were higher in the $\mathrm{De}$ cember samples than in the March samples by about 73 and 55 folds, respectively. The concentrations of other heavy metals $(\mathrm{Cr}, \mathrm{Cd}$, and $\mathrm{Fe}$ ) were also elevated in the December samples compared to the March samples by about 2.4-14.8 folds.

\section{DISCUSSION}

Changes in carbon isotope values of the primary producers are strongly influenced by the physical and biogeochemical environments including water temperature, light, growth rate and so on (Cornwall et al. 2015, Mackey et al. 2015, Drobnitch et al. 2017). With all the other conditions remaining equal, lower water temperature or a greater amount of photosynthesis increase the carbon isotope ratio due to lower discrimination in plant when absorbing from carbon source (Carvalho et al. 2009, 2010). However, the influence of higher photosynthesis is much stronger than that of lower temperature on carbon discrimination.

When Undaria pinnatifida culturing began by transplanting the seeded-strings into the ocean at around October / November, January represented 60-80 days of grow-out. The average surface water temperature for November and February at Gijang stations (during 20042012), was reported by Nationwide Marine Environmental Measurement Network (NMEMN, http://www.meis. go.kr), to be 18.1 and $12.4^{\circ} \mathrm{C}$, respectively. There was a decrease of approximately $4-7^{\circ} \mathrm{C}$ during this period, whereas, between February and May (average $14.5^{\circ} \mathrm{C}$ ), there was an increase of approximately $1-3^{\circ} \mathrm{C}$. According to Lee and Sohn (1993), seaweeds cultured from November to the following April, show about $64-69 \%$ of growth in length during the initial 75 day, with January having the highest growth rate at $2.3-2.8 \mathrm{~cm} \mathrm{day}^{-1}$. However, after that point, the growth rate decreases rapidly to below $1 \mathrm{~cm}$ day $^{1}$. From the time the seeded seed-line is transplanted in the ocean to about 60-80 days of grow-out, the water temperature decreases and the growth rate is also the highest. Therefore, the increase in the carbon isotope ratio in the blade samples reflects these two effects for the period. In the coastal regions under study, the monthly
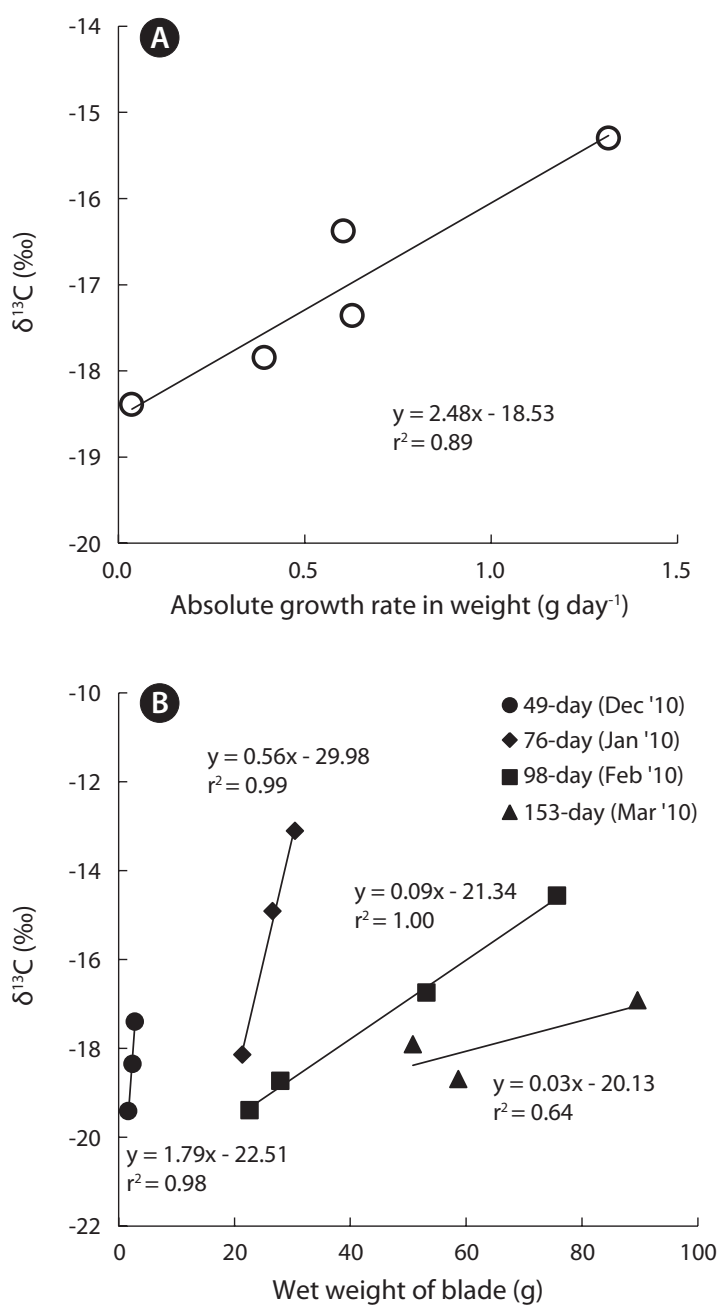

Fig. 3. Relationships between monthly average $\delta^{13} \mathrm{C}$ and growth rate in weight $(A)$, and between $\delta^{13} \mathrm{C}$ and wet weight for each blade (B) of Undaria pinnatifida sampled in Gijang on the east coast of Korea from January 2010 to January 2011.

average carbon isotope value in the $U$. pinnatifida blades have a high positive linear correlation $\left(\mathrm{r}^{2}=0.89\right)$ with the absolute growth rate in weight (Fig. 3A), suggesting that carbon isotope discrimination becomes lower with higher growth rate.

Additionally, Carvalho et al. (2009) also reported a very high correlation between the blade growth rate and the carbon isotope discrimination in mariculture $U$. pinnatifi$d a$ from Okkirai Bay in northeastern Japan. They said that among the various aspects of growth rate (absolute in length, absolute in weight, and relative in weight), especially growth rate in relation to weight, showed the highest correlation $\left(r^{2}=0.97\right)$, and insisted that the growth rate is the most important factor in carbon stable isotope discrimination. Moreover, when samples share the same 
transplantation period, i.e., the same amount of time being exposed to the environment, the samples with a higher wet weight presumably have the higher growth rate. Investigation of the correlations between wet weight and carbon isotope ratio in U. pinnatifida samples collected during the same month showed a distinct tendency for the samples with the higher wet weight to have a higher carbon isotope for each month (Fig. 3B).

Linear correlations $\left(\mathrm{r}^{2}\right)$ between carbon isotope ratio and the wet weight of the samples collected during January, February, and December of 2010 showed a very high range (0.98-1.0), whereas only the samples collected during March showed a slightly lower correlation at 0.64. Moreover, the slope of the monthly linear correlation was the highest in young blades sampled in December (1.79), while the lowest was in adult blades sampled in March (0.03). In other words, young blade samples collected during December 2010 showed the most drastic difference in carbon isotope ratio over a parallel increase in weight $\left(\Delta \delta^{13} \mathrm{C} / \Delta\right.$ weight $)$, and as the blades became more mature, an increase in weight had less impact on isotope ratio. This is because as the organism grows, there is more increase in the old tissues that are not intricately involved in maintaining life than that of the young tissues serving the essential function of growth or photosynthesis (Lee 2008).

Therefore, in samples are collected in a similar month I season, and under the same environmental condition, the changes in the slope of the wet weight and the carbon isotope ratio could be an indirect indicator of seaweed's growth. Meanwhile, there was no distinct correlation between mean monthly water temperature and carbon isotope ratio, which could be attributed to the difficulty in differentiating the effects of water temperature and growth rate, with growth rate typically having a more robust impact. An ideal case of carbon isotope ratio becoming higher at lower water temperature is even more difficult to observe on-site, since the growth rate is generally higher with higher water temperature thus offsetting such effect (Carvalho et al. 2010)

The nitrogen content and isotope ratio of macroalgae depend on the concentration and the availability of nitrogen in the surrounding environment (Dean and Hurd 2007, Orlandi et al. 2017, Piñón-Gimate et al. 2017). Macroalgae are incapable of storing large nitrate pools, and thus they are known to rapidly assimilate nitrogen from the surrounding environment (Dean and Hurd 2007, Kang and Kim 2016). Orlandi et al. (2017) emphasized the rapid nitrogen uptake of Ulva lactuca requiring only a few days to approach isotopic equilibrium with differ-

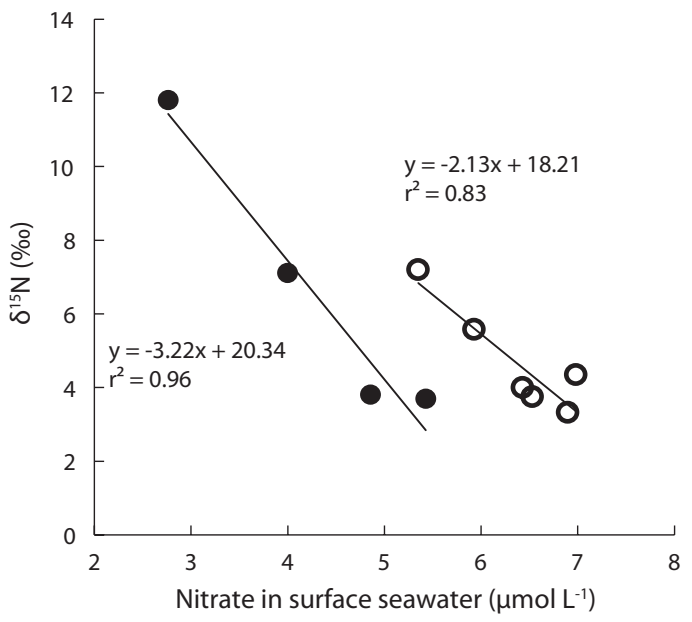

Fig. 4. Relationships between monthly average $\delta^{15} \mathrm{~N}$ for Undaria pinnatifida and nitrate concentration in surface seawater at Gijang (open circle), and $\delta^{15} \mathrm{~N}$ for U. pinnatifida sampled at Tongyeong, Dajin and Gwangyang in May (Yun et al. 2006, Kang et al. 2007) and Gijang in February and nitrate concentration at each site measured by nationwide Marine Environmental Measurement Network (http:// www.meis.go.kr) (closed circle).

ent nitrogenous sources and concentrations. The average nitrate in surface seawater of Gijang stations measured by NMEMN in February, May, August, and November during a 9-year period (2004-2012) was $5.4 \pm 1.4 \mu \mathrm{M}$, peaking in February. The values decreased gradually in May $(2.5 \pm 1.7$ $\mu \mathrm{M})$ and August $(1.8 \pm 1.5 \mu \mathrm{M})$ and then increased again in November $(5.1 \pm 3.2 \mu \mathrm{M})$. Using surface seawater nitrate levels measured by NMEMN during November of 2009, February, May, August, and November of 2010, and February of 2011 from Gijang stations, the nitrate concentration during those collection periods were estimated with an assumption of linear changes in concentrations over time between observational periods. And the correlations with nitrogen isotope ratio values of $U$. pinnatifida and nitrate concentrations in surface water estimated, showed very high negative correlations $\left(r^{2}=0.83\right)$ (Fig. 4).

When nitrate was $>6 \mu \mathrm{M}, \delta^{15} \mathrm{~N}$ was $3.3-4.4 \%$, whereas when nitrate was $<6 \mu \mathrm{M}$, the value increased to $\geq 5.5 \%$. U. pinnatifida samples collected from Sanriku Ria Coast of Japan showed 1-2\% in seaweed samples from January and March when DIN (dissolved inorganic nitrogen) was high, and 3-6\% in seaweed samples from June and July when DIN was low (Carvalho et al. 2008). This was because $U$. pinnatifida has a low capacity to store nitrogen in their body so that when nitrogen concentrations dropped, a more intensive uptake occurred leading to lower fractionation, which then resulted in the higher nitrogen isotope ratio values (Peterson and Fry 1987). 
The nitrogen isotope ratio in the present study, as well as those in the rocky subtidal zone in Daejin (East Sea), and the intertidal zones in Gwangyang, and Tongyeong (South Sea) in Korea, showed a range of approximately 3 12\%o (Yun et al. 2006, Kang et al. 2007). Although there are differences based on collection period and location, as well as whether it was naturally grown or cultured, the regional variation in nitrogen isotope ratio at up to $<9 \%$, as much larger than that of carbon. There was a high negative correlation between nitrogen isotope ratio values in seaweed blades and the average nitrate in surface seawater measured in May from three coastal zones and in February from the coastal zone (Gijang) during 2004-2010 (1-5 stations per coastal zone measured by NMEMN) $\left(\mathrm{r}^{2}\right.$ $=0.96$ ) (Fig. 4). These observations indicate that the nitrogen isotope ratio of $U$. pinnatifida is significantly affected by the nitrogen concentration in the surrounding environments, hence the $\delta^{15} \mathrm{~N}$ of the seaweed could be used as an indicator for coastal nitrogen variations as well as a discriminating factor for the origin of those seaweed production.

When heavy metal concentrations of maricultured adult $U$. pinnatifida from Gijang were compared to edible seaweeds commercialized for human consumption from Spain (Besada et al. 2009), the concentration of $\mathrm{Cu}$ was higher by about 5-8 folds, the peak concentration of $\mathrm{Cd}$ was lower by $20 \%$, and the other metal had similar concentration ranges. Previously, Park et al. (2012) reported that concentrations of $\mathrm{Fe}$ and $\mathrm{Cu}$ in seaweed samples collected from Jindo, Wando, and Gijang during March-July of 2006 showed a range of 58-95 and 0.8-1.9 $\mathrm{mg} \mathrm{kg}_{\mathrm{dry}}{ }^{-1}$, respectively. The concentration of Fe showed a range similar to that observed in the present study, but $\mathrm{Cu}$ showed relatively lower concentrations. Since elements such as $\mathrm{Cu}$ and etc. that are closely associated with physiological activities that correlate with growth rate, the average
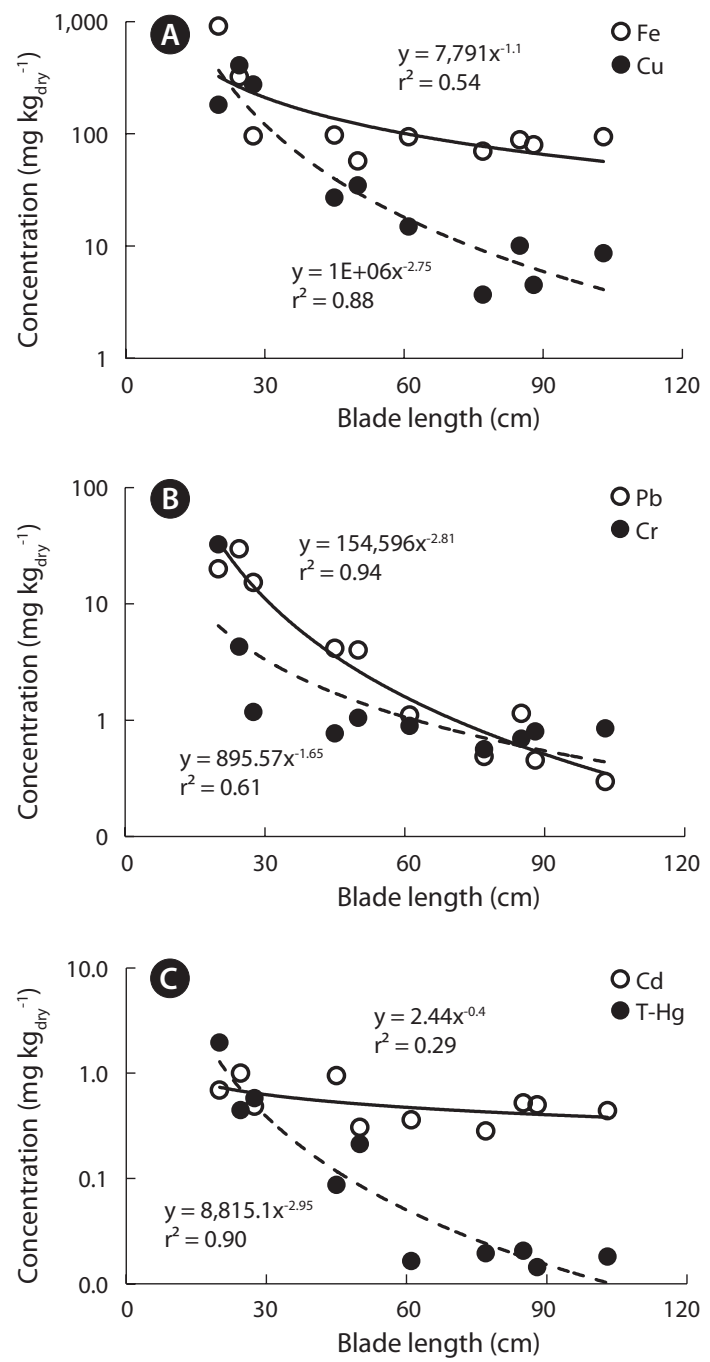

Fig. 5. Relationships between blade length and concentrations ( $\mathrm{mg}$ $\mathrm{kg}_{\text {dry }}^{-1}$ ) of $\mathrm{Cu}$ and $\mathrm{Fe}(\mathrm{A}), \mathrm{Pb}$ and $\mathrm{Cr}(\mathrm{B})$, and $\mathrm{Cd}$ and $\mathrm{Hg}(\mathrm{C})$ for Undaria pinnatifida maricultured in Gijang on the east coast of Korea from January 2010 to January 2011.

Table 2. Pearson correlation coefficients between heavy metal concentrations in blades and morphological properties of Undaria pinnatifida maricultured in Gijang on the east coast of Korea

\begin{tabular}{lcccccc}
\hline & $\mathbf{C u}$ & $\mathbf{C d}$ & $\mathbf{P b}$ & $\mathbf{C r}$ & $\mathbf{F e}$ & T-Hg \\
\hline Days transplanted & -0.63 & -0.22 & $-0.66^{*}$ & -0.38 & -0.42 & -0.53 \\
Wet weight (g) & -0.58 & -0.44 & -0.63 & -0.36 & -0.39 & -0.50 \\
Surface area $\left(\mathrm{cm}^{2}\right)$ & -0.58 & -0.41 & -0.62 & -0.36 & -0.40 & -0.50 \\
Blade length (cm) & $-0.76^{*}$ & -0.53 & $-0.82^{* *}$ & -0.51 & -0.57 & $-0.68^{*}$ \\
Blade width (cm) & $-0.66^{*}$ & -0.57 & $-0.72^{*}$ & -0.43 & -0.48 & -0.59 \\
Weight / Area & -0.63 & -0.37 & $-0.67^{*}$ & -0.44 & -0.48 & -0.56 \\
\hline
\end{tabular}

Asterisks $\left({ }^{*}\right.$ and $\left.{ }^{* *}\right)$ denote significant correlations at $p<0.05$ and $p<0.01$, respectively $(n=10)$. 
concentration in the present study was higher due to the inclusion of the actively growing young blades.

The concentrations of $\mathrm{Cu}, \mathrm{Hg}$, and $\mathrm{Pb}$ were approximately 30-, 55- and 73-fold, higher in young blades of $U$. pinnatifida that are actively growing than in adults. This was consistent with the highest $\mathrm{Cu}$ concentrations reported in meristem and young blades of Laminaria digitata (Stengel et al. 2005). So, heavy metals in U. pinnatifida showed higher concentration per unit weight when growth indices, such as blade weight, length, and width, were lower, meaning when the blades were younger (Table 2). In particular, $\mathrm{Cu}, \mathrm{Hg}$, and $\mathrm{Pb}$ showed very high negative correlations with blade length $\left(\mathrm{r}^{2}=0.88-0.94\right)$ (Fig. $5)$. When the macroalgae grow rapidly, the accumulated elements be diluted and reduced their concentrations (Malea et al. 2015). Coelho et al. (2005) also suggested that the growth rate and surface / volume ratios affected to the concentration of $\mathrm{Hg}$ in the blades of macroalgae sampled at Hg-contaminated coastal lagoons. However, seasonal and spatial variations in metal concentrations of surface seawater measured at 6 stations located in east coast of Korea, ranged 0.060-0.319 $\mu \mathrm{g} \mathrm{L} \mathrm{L}^{-1}$ in $\mathrm{Cu}, 0.011-0.058 \mu \mathrm{g} \mathrm{L} \mathrm{L}^{-1}$ in $\mathrm{Cd}$ and 0.015-0.160 $\mu \mathrm{g} \mathrm{L}^{-1}$ in Pb during spring, summer and fall of 2005 (Kim et al. 2007). Metal concentrations at 6 coastal areas were usually higher in summer than other seasons, due to rainfall input from land and seasonal variation at a station ranged only 2 to 4 fold, much lower than those of blades in U. pinnatifida. Therefore, variations of heavy metal concentrations depending on growth of mariculture $U$. pinnatifida from Gijang can be used as baseline data on monitoring heavy metal in the corresponding coastal areas.

\section{ACKNOWLEDGEMENTS}

This research was supported by a grant from the National Institute of Fisheries Science in Korea (R2017040).

\section{REFERENCES}

Ale, M. T., Mikkelsen, J. D. \& Meyer, A. S. 2011. Differential growth response of Ulva lactuca to ammonium and nitrate assimilation. J. Appl. Phycol. 23:345-351.

Besada, V., Andrade, J. M., Schultze, F. \& González, J. J. 2009. Heavy metals in edible seaweeds commercialised for human consumption. J. Mar. Syst. 75:305-313.

Carvalho, M. C., Hayashizaki, K. \& Ogawa, H. 2008. Environment determines nitrogen content and stable isotope composition in the sporophyte of Undaria pinnatifida (Harvey) Suringar. J. Appl. Phycol. 20:695-703.

Carvalho, M. C., Hayashizaki, K. -I. \& Ogawa, H. 2009. Carbon stable isotope discrimination: a possible growth index for the kelp Undaria pinnatifida. Mar. Ecol. Prog. Ser. 381:71-82.

Carvalho, M. C., Hayashizaki, K. -I. \& Ogawa, H. 2010. Temperature effect on carbon isotopic discrimination by Undaria pinnatifida (Phaeophyta) in a closed experimental system. J. Phycol. 46:1180-1186.

Coelho, J. P., Pereira, M. E., Duarte, A. \& Pardal, M. A. 2005. Macroalgae response to a mercury contamination gradient in a temperate coastal lagoon (Ria de Aveiro, Portugal). Estuar. Coast. Shelf Sci. 65:492-500.

Cornwall, C. E., Revill, A. T. \& Hurd, C. L. 2015. High prevalence of diffusive uptake of $\mathrm{CO}_{2}$ by macroalgae in a temperate subtidal ecosystem. Photosynth. Res. 124:181190.

Dean, P. R. \& Hurd, C. L. 2007. Seasonal growth, erosion rates, and nitrogen and photosynthetic ecophysiology of $\mathrm{Un}$ daria pinnatifida (Heterokontophyta) in southern New Zealand. J. Phycol. 43:1138-1148.

Drobnitch, S. T., Pochron, T. \& Miranda, C. 2017. Patterns and drivers of $\delta^{13} \mathrm{C}$ variation in the giant kelp, Macrocystis pyrifera. Limnol. Oceanogr. Advanced online publication. https://doi.org/10.1002/lno.10675.

Kang, C. -K., Choy, E. J., Song, H. S., Park, H. J., Soe, I. -S., Jo, Q. \& Lee, K. -S. 2007. Isotopic determination of food sources of benthic invertebrates in two different macroalgal habitats in the Korean coasts. The Sea 12:380-389.

Kang, E. J. \& Kim, K. Y. 2016. Effects of future climate conditions on photosynthesis and biochemical component of Ulva pertusa (Chlorophyta). Algae 31:49-59.

Kim, J. -H., Kang, E., J., Kim, K., Jeong, H. J., Lee, K., Edwards, M. S., Park, M. G., Lee, B. -G. \& Kim, K. Y. 2015. Evaluation of carbon flux in vegetative bay based on ecosystem production and $\mathrm{CO}_{2}$ exchange driven by coastal autotrophs. Algae 30:121-137.

Kim, K. T., Jang, S. H., Kim, E. S., Cho, S. R., Park, J. K., Moon, D. S. \& Kim, H. J. 2007. Distribution of dissolved trace metals in the deep oceans waters of the East Sea. J. Korean Soc. Mar. Environ. Saf. 13:1-7.

Klenell, M., Snoeijs, P. \& Pedersén, M. 2004. Active carbon uptake in Laminaria digitata and L. saccharina (Phaeophyta) is driven by a proton pump in the plasma membrane. Hydrobiologia 514:41-53.

Lee, J. -A., Sunwoo, Y. -I., Lee, H. -J., Park, I. -H. \& Chung, I. -K. 1989. The effects of copper on the early stages of Undaria pinnatifida (Harv.) Suringar (Laminariales, Phaeophyta) under temperature-irradiance gradient. 
Korean J. Phycol. 4:41-53.

Lee, K. Y. \& Sohn, C. H. 1993. Morphological characteristics and growth of two forms of sea mustard, Undaria pinnatifida f. distans and U. pinnatifida f. typica. J. Aquac. 6:71-87.

Lee, R. E. 2008. Phycology. Cambridge University Press, Cambridge, pp. 504-520.

Mackey, A. P., Hyndes, G. A., Carvalho, M. C. \& Eyre, B. D. 2015. Physical and biogeochemical correlates of spatiotemporal variation in the $\delta^{13} \mathrm{C}$ of marine macroalgae. Estuar. Coast. Shelf Sci. 157:7-18.

Malea, P., Chatziapostolou, A. \& Kevrekidis, T. 2015. Trace element seasonality in marine macroalgae of different functional-form groups. Mar. Environ. Res. 103:18-26.

Oakes, J. M. \& Eyre, B. D. 2015. Wastewater nitrogen and trace metal uptake by biota on a high-energy rocky shore detected using stable isotopes. Mar. Pollut. Bull. 100:406413.

Orlandi, L., Calizza, E., Careddu, G., Carlino, P., Costantini, M. L. \& Rossi, L. 2017. The effects of nitrogen pollutants on the isotopic signal $\left(\delta^{15} \mathrm{~N}\right)$ of Ulva lactuca: microcosm experiments. Mar. Pollut. Bull. 115:429-435.

Park, H. J., Han, E., Lee, Y. -J. \& Kang, C. -K. 2016. Tropic link- age of a temperate intertidal microbenthic food web under opportunistic macroalgal blooms: a stable isotope approach. Mar. Pollut. Bull. 111:86-94.

Park, K. -J., Kim, B. Y., Park, S. K., Lee, J. -H., Kim, Y. S., Choi, H. G. \& Nam, K. W. 2012. Morphological and biochemical differences in three Undaria pinnatifida populations in Korea. Algae 27:189-196.

Peterson, B. J. \& Fry, B. 1987. Stable isotopes in ecosystem studies. Annu. Rev. Ecol. Syst. 18:293-320.

Piñón-Gimate, A., Espinosa-Andrade, N., Sánchez, A. \& Casas-Valdez, M. 2017. Nitrogen isotopic characterization of macroalgae blooms from different sites within a subtropical bay in the Gulf of California. Mar. Pollut. Bull. 116:130-136.

Stengel, D. B., McGrath, H. \& Morrison, L. J. 2005. Tissue Cu, Fe and Mn concentrations in different-aged and different functional thallus regions of three brown algae from western Ireland. Estuar. Coast. Shelf Sci. 65:687-696.

Yun, S. -G., Yoon, B. -S., Paik, S. -G. \& Kang, C. -K. 2006. The origin of organic matters utilized by soft bottom macrozoobenthos in Tongyeong. J. Korean Fish. Soc. 39:189197. 